\title{
KEKERASAN VERBAL DALAM MEDIA SOSIAL FACEBOOK
}

\author{
Dwi Yuliantoro Seno Utoro*1, Susetyo ${ }^{2}$, Ria Ariesta ${ }^{3}$ \\ ${ }^{1,2,3}$ Program Studi Magister Pendidikan Bahasa Indonesia, Universitas Bengkulu \\ Jln. W.R. Supratman Kandang Limun, Bengkulu, Indonesia \\ Email: dwiyuliantorosenoutoro@gmail.com ${ }^{\star 1}$, tsetyo55@gmail.com ${ }^{2}$, \\ riaariesta17@gmail.com ${ }^{3}$
}

\begin{abstract}
Abstrak
Media sosial di Indonesia seiring waktu telah berkembang dengan pesat. Hal itu didukung dengan infrastruktur internet yang semakin maju, misalnya akses wifi, jaringan fiber, dan lain sebagainya. Orang-orang Indonesia makin hari makin aktif dalam dunia media sosial, dengan tingkat penetrasi yang mencapai puluhan juta orang. Adanya media sosial tentunya memiliki dampak, baik positif maupun negatif sehingga konten-konten apapun dapat viral dengan mudah. Pada saat berinteraksi atau berkomunikasi dengan menggunakan media ini, begitu banyak orang yang menyelahgunakan etika bersosialisasi di dunia maya dengan mengunggah atau mengomentari postingan menggunakan kata-kata kasar yang disebut kekerasan verbal. Penelitian ini bertujuan untuk mengetahui bentuk bahasa yang digunakan dalam media sosial dan bentuk komentar terhadap postingan di media sosial Facebook. Metode penelitian ini menggunakan metode deskriptif kualitatif. Sumber data penelitian berasal dari media sosial Facebook, sedangkan data berupa komentar kekerasan verbal di Facebook. Teknik pengumpulan data menggunakan teknik dokumentasi. Analisis data menggunakan teknik analisis kualitatif dan teknik pemeriksaan keabsahan data yang dilakukan dengan teknik pemeriksaan ketekunan pengamatan dan memberchek. Hasil penelitian menunjukkan bahwa bentuk bahasa yang digunakan dalam kalimat Facebook memiliki kelugasan, ketepatan, dan kejelasan. Sementara itu, bentuk komentar terhadap postingan di Facebook berupa kekerasan verbal meliputi: umpatan, hiperbola, disfemisme, stigmatisasi, dan asosiasi pada binatang. Bahasa kekerasan verbal yang ada di Facebook menunjukkan bahwa masyarakat Indonesia masih belum santun dalam berbahasa sehingga menjadi masukan bagi pemerintah dan lembaga pendidikan untuk memberikan langkah strategis untuk mengatasi permasalahan tersebut.
\end{abstract}

Kata kunci: kekerasan verbal, media sosial, Facebook

\section{VERBAL ABUSE ON FACEBOOK SOCIAL MEDIA}

\begin{abstract}
Social media in Indonesia has developed rapidly over time. This is supported by increasingly advanced internet infrastructure, such as wifi access, fiber networks, and so on. Indonesians are increasingly active in the world of social media, with a penetration rate of tens of millions of people. The existence of social media certainly has an impact, both positive and negative so that any content can go viral easily. When interacting or communicating using this media, so many people abuse the ethics of socializing in cyberspace by uploading or commenting on posts using harsh words which are called verbal violence. This study aims to determine the form
\end{abstract}


of language used in social media and the form of comments on posts on social media Facebook. This research method uses a qualitative descriptive method. The source of research data comes from social media Facebook, while the data is in the form of verbal abuse comments on Facebook. Data collection techniques using documentation techniques. Data analysis used qualitative analysis techniques and data validity checking techniques performed by checking observation and memberchek persistence. The results showed that the form of the language used in the Facebook sentence had straightforwardness, accuracy, and clarity. Meanwhile, the forms of comments on posts on Facebook in the form of verbal abuse include: swearing, hyperbole, dysphemism, stigmatization, and association with animals. The language of verbal violence on Facebook shows that Indonesian people are still not polite in language, so it becomes input for the government and educational institutions to provide strategic steps to overcome this problem.

Keywords: verbal abuse, social media, Facebook

\section{A. Pendahuluan}

Teknologi informasi dan komunikasi (TIK) pada era ini berkembang sangat pesat serta dibutuhkan di dalam kehidupan sehari-hari. Saat ini semua smartphone atau gawai dijejali lebih dari dua aplikasi media sosial yang semuanya dimanfaatkan dan memiliki peran tersendiri dalam komunikasi modern. Tingginya pengguna konten media sosial memudahkan orang untuk berkomunikasi. Media sosial merupakan perkembangan mutakhir dari teknologi-teknologi perkembangan web baru berbasis internet, yang memudahkan semua orang untuk dapat berkomunikasi, berpartisipasi, saling berbagi dan membentuk sebuah jaringan secara daring, sehingga dapat menyebar luaskan konten mereka sendiri yang ada di dunia maya (Asmaya \& Rumyeni, 2015:2). Komunikasi merupakan penyampaian pikiran atau perasaan oleh seseorang kepada orang lain dengan menggunakan lambang-lambang yang bermakna bagi kedua pihak, dalam situasi tertentu, menggunakan media tertentu untuk merubah sikap atau tingkah laku seseorang atau sejumlah orang sehingga menimbulkan efek tertentu yang diharapkan (Effendy, 2003:13; Noermanzah, 2019:307). Contoh dari media sosial meliputi Facebook, Whatsapp, BBM, Line, Chat, dan lain sebagainya.

Masyarakat Indonesia yang menggunakan media sosial sebagai alat komunikasi semakin hari semakin banyak, sehingga konten-konten apapun dapat viral dengan mudah seperti misalnya peristiwa-peristiwa unik sampai pada hal-hal kecil yang mungkin sebelumnya tidak pernah terpikirkan akan viral. Petisi-petisi daring juga semakin marak yang menunjukkan bahwa pengguna media sosial tidak hanya menyadari fungsi media sosial untuk berinteraksi, tetapi juga untuk

Silampari Bisa: Jurnal Penelitian Pendidikan Bahasa Indonesia, Daerah, dan Asing Vol. 3, No. 2, 2020 
melakukan gerakan-gerakan atau mendukung gagasan-gagasan tertentu agar mereka dapat berkontribusi dalam mengatur perkembangan masyarakat yang ada di sekitarnya, seperti misalnya petisi penghentian siaran televisi yang tidak mendidik, pembubaran gerakan massa tertentu dan lain sebagainya (Hidaya \& Khusnia, 2019:129-130).

Adanya media sosial ini tentunya terdapat efek atau pengaruh media sosial yang juga perlu untuk diwaspadai. Kekerasan pada orang lain yang bersifat untuk merendahkan, menakuti ataupun mengancam yang biasanya disebut sebagai "bullying atau violence" (Wardani \& Fajriansyah, 2017:18). Simbolon (2012:234) mengatakan bahwa bullying adalah perilaku agresif dan menekan, baik dalam bentuk tindakan fisik secara langsung atau menyerang melalui kata-kata. Pelakunya tidak hanya para senior, tetapi juga guru, orang tua, dan orang-orang di lingkungan sekitar.

Saat dunia nyata kita akan memberi pesan pribadi (kritik atau teguran) tentu tidak dapat dilakukan di depan umum, bahkan teguran atasan kepada bawahan juga harus dilakukan secara santun, bukan di depan orang lain. Lain halnya di dunia maya, sebagai individu yang sewajarnya sudah mengerti norma-norma pergaulan sehari-hari, kita semua seharusnya dapat mengetahui etika bersosialisasi dunia nyata ke dalam dunia maya. Cerita bahwa dunia maya adalah dunia tanpa aturan dan tanpa etika sama sekali tidak benar. Tidak adanya batasan ruang dan waktu.

Pada saat berinteraksi atau berkomunikasi dengan menggunakan media ini, begitu banyak orang yang menyelahgunakan etika bersosialisasi di dunia maya dengan tidak memikirkan resiko apa saja yang mereka dapatkan jika sembarangan mengunggah sesuatu, harus juga menjadi pengingat bagi kita untuk senantiasa berhati-hati dalam mengutarakan pendapat, baik di dunia maya maupun dunia nyata, jangan sampai menggunakan kekerasan verbal. Kekerasan verbal biasanya berupa perilaku verbal dimana pelaku melakukan pola komunikasi yang berisi penghinaan, ataupun kata-kata yang melecehkan (Putra, 2015:284). Pelaku biasanya melakukan tindakan mental abuse, menyalahkan, melabeli, atau juga mengkambinghitamkan. Verbal abuse merupakan semua bentuk tindakan 
ucapan yang mempunyai sifat menghina, membentak, memaki, dan menakuti dengan mengeluarkan kata-kata tidak pantas, seperti mencemarkan nama baik orang lain, penghinaan agama, mempropokasi, bahkan menyebarkan informasi bohong (Lestari, 2016:16).

Permasalahan yang timbul dari kasus kekerasan verbal dalam media sosial adalah salah satu tindak kriminal di dunia internet, yaitu cyber bullying. Cyber bullying lebih mudah dilakukan karena si pelaku tidak perlu bertatap muka dengan orang lain yang menjadi target cyber bullying. Mereka bisa mengatakan hal-hal yang buruk dan dengan mudah mengintimidasi orang lain karena mereka menggunakan internet atau ponsel pintar, tanpa harus melihat akibat yang ditimbulkan pada orang lain. Cyber bullying pada umumnya dilakukan melalui media situs jejaring sosial seperti Facebook, Twitter, Instagram. Cyber bullying merupakan bentuk bully yang lebih parah yang mengakibatkan dampak psikologis terutama pada anak-anak dibandingkan yang terjadi di dunia nyata karena dapat menjangkau siapapun orang-orang yang menjadi korban cyber bully, dapat diakses kapan pun (Hana \& Suwarti, 2020:1).

Beragam faktor untuk beragam problematik. Interaksi antarpribadi menjadi tidak terkontrol karena bentuk kekerasan verbal itu menstimulus satu dengan lainnya. Jika terus berlanjut, efek akan mempengaruhi seseorang dalam waktu yang pendek hingga waktu panjang. Jika ditinjau dari bentuk kebudayaan, kekerasan verbal dalam berkomunikasi memberi citra negatif bagi bangsa Indonesia. Indikasi kecerdasan linguistik perlu diperhatikan lebih lanjut dan menjadi sorotan ilmu kebahasaan terutama dalam hal berbahasa Indonesia yang baik dan benar dalam berinteraksi dan berkomunikasi antar sesama. Mengucapkan kata apapun tidaklah salah, tetapi menggunakan kata apapun memerlukan telaah. Oleh sebab itu, kecerdasan linguistik seseorang memperlihatkan kemampuannya dalam mengelola diksi dan emosi sesuai konteks situasi.

Begitu pula halnya dengan mengomentari postingan di media sosial menggunakan kata-kata yang mengandung unsur kekerasan verbal, akan menimbulkan reaksi dari berbagai pihak. Berkomentar dengan menggunakan 
kekerasan verbal bertolak belakang dengan konsep kesantunan berbahasa sebagai indikator kecerdasan linguistik, sama halnya dengan etika berkomunikasi. Dalam kehidupan bersosial di tengah masyarakat, istilah etika dikaitkan dengan moralitas seseorang (Nugroho, 2018:29). Orang yang tidak memiliki etika yang baik sering disebut tidak bermoral karena tindakan dan perkataan yang diambil tidak melalui pertimbangan baik dan buruk. Etika bisa terlihat dari cara netizen bertutur. Tidak adanya filter atau saringan pertimbangan nilai baik dan buruk merupakan awal dari bencana penyalahgunaan media sosial di era ini.

Saat ini banyak orang yang mengomentari postingan menggunakan kekerasan verbal. Hal tersebut dikarenakan para netizen memiliki kebebasan dalam mengeksplor media sosial tersebut sehingga mereka bebas berujar di media sosial tanpa berpikir akibat yang terjadi setelahnya. Peneliti memfokuskan memilih media sosial Facebook dalam meneliti kekerasan verbal dalam media sosial. Menurut Handayani (2009:1) Facebook (fesbuk) atau yang sering kita sebut "Fb" adalah situs jejaring sosial dunia maya. Peneliti memiliki alasan karena, media sosial Facebook lebih banyak menampilkan konten kekerasan verbal dibandingkan media sosial lain. Selain itu, Facebook juga jangkauan pertemanan atau anggota yang terlibat di dalamnya lebih banyak dan luas bahkan seluruh dunia, sehingga peneliti bisa mendapatkan data yang lebih banyak.

Munculnya bentuk kekerasan verbal dalam Facebook menjadi salah satu alasan penulis tertarik melakukan penelitian terhadap fenomena kekerasan verbal dalam komunikasi khususnya di Facebook. Terkait dengan bentuk bahasa yang digunakan dan bentuk komentar terhadap postingan di Facebook.

Penelitian terdahulu dijadikan sumber rujukan penulis, seperti penelitian yang dilakukan oleh Putra (2015) berjudul Analisis Isi Kekerasan Verbal pada Tayangan Pesbukers di ANTV, menunjukkan bahwa program komedi Pesbukers, yang merupakan program komedi unggulan ANTV, ternyata terdapat 1.396 kemunculan adegan kekerasan secara verbal. Hal ini terjadi disebabkan orang-orang terkadang tidak menyadari bahwa apa yang dilakukannya adalah kekerasan, karena menganggap hal itu sudah biasa dan sebatas gurauan semata. Kekerasan verbal lebih sulit dikenali, antara lain karena seringkali mengatasnamakan konteks 
humor. Kemudian, penelitian (Nisa \& Wahid, 2014) dengan judul Analisis Isi Kekerasan Verbal dalam Sinetron "Tukang Bubur Naik Haji The Series" di RCTI (Analisis Isi Episode 396-407) yang dipublikasikan di Jurnal Komunikasi Fakultas Ilmu Komunikasi Universitas Budi Luhur, membahas presentase kecenderungan muatan kekerasan verbal dalam tayangan sinetron Tukang Bubur Naik Haji The Series.

Penelitian dari Fitriana dkk., (2015) berjudul Faktor-faktor yang Berhubungan dengan Perilaku Orang Tua dalam Melakukan Kekerasan Verbal terhadap Anak Usia Pra-Sekolah, menunjukkan bahwa terdapat hubungan antara umur dengan perilaku orang tua melakukan kekerasan verbal pada anaknya, tidak terdapat hubungan antara pendidikan dengan perilaku orang tua melakukan kekerasan verbal pada, tidak terdapat hubungan antara pendapatan dengan perilaku orang tua melakukan kekerasan verbal pada anaknya, terdapat hubungan antara pengetahuan dengan perilaku orang tua melakukan kekerasan verbal pada anaknya, terdapat hubungan sikap dengan perilaku orang tua melakukan kekerasan verbal pada anaknya, terdapat hubungan pengalaman dengan perilaku orang tua melakukan kekerasan verbal pada anaknya, dan terdapat hubungan lingkungan dengan perilaku orang tua melakukan kekerasan verbal pada anaknya.

Sebagian besar penelitian yang telah dilakukan adalah menganalisis kekerasan verbal dari aspek intensitas kemunculannya dan faktor penyebabnya, sedangkan dari segi bentuk bahasa yang digunakan dan bentuk komentar belum menjadi sorotan peneliti terdahulu. Penelitiian terdahulu memiliki persamaan dengan penelitian ini, sehingga beberapa uraian di antaranya dimasukkan ke dalam penelitian ini sebagai referensi. Persamaan penelitian terdahulu dengan penelitian ini yaitu masa-sama mengacu pada analisis yang mengandung kekerasan verbal atau ucapan bernada kasar, sementara itu perbedaannya dalam penelitian terdahulu fokus mengkajiaannya intensitas penggunaan dan faktor penyebab, sedangkan penelitian ini mengkaji konteknya berdasarkan bentuk bahasa dan bentuk komentar kekerasan verbal dalam Facebook. 


\section{B. Metode Penelitian}

Penelitian ini menggunakan menggunakan metode deskriptif kualitatif. Penelitian kualitatif adalah penelitian yang dilakukan secara berulang-ulang pada penelitian yang sama sampai ditentukan informasi yang objektif, valid, dan konsisten (Sugiyono, 2015:12). Tujuan dari penelitian deskriptif ini memberikan deskripsi, gambaran, atau lukisan secara sistematis, faktual, akurat mengenai fenomena komunikasi kekerasan verbal yang diteliti. Penelitian ini menggunakan pendekatan kualitatif, karena data yang diperoleh akan dideskripsikan dalam bentuk kata-kata, yaitu berupa bentuk bahasa yang digunakan dalam media sosial dan bentuk komentar terhadap postingan di media sosial. Hasil dari penelitian ini berupa deskripsi tentang bagaimana bentuk bahasa yang digunakan dalam media sosial dan bentuk komentar terhadap postingan di media sosial.

Analisis data penelitian menggunakan metode analisis isi. Metode ini bukan hanya untuk mempelajari karakteristik isi komunikasi, tetapi juga untuk menarik kesimpulan mengenai sifat komunikator, keadaan khalayak, maupun efek komunikasi (Bungin, 2008:188). Penelitian ini dilakukan dengan cara mengambil data di Facebook yang berupa postingan dan komentar-komentar netizen yang mengandung unsur kekerasan verbal. Alat yang digunakan untuk penelitian adalah handphone android yang mengakses media sosial Facebook. Waktu penelitian dilaksanakan pada bulan Januari sampai Maret 2019.

Prosedur dalam penelitian ini diawali dengan pengumpulan data. Dalam proses pengumpulan data tersebut peneliti terlebih dahulu mengakses Facebook menggunakan handphone android, seterusnya membaca dan menyimak tampilan di media sosial tersebut, kemudian memilih muatan dan komentar yang mengandung kategori kekerasan verbal, selanjutnya menganalisis bentuk bahasa yang digunakan dan bentuk komentar terhadap postingan. Sementara itu, bentuk data yang ditemukan adalah bentuk kekerasan verbal yang ada di Facebook, khusus yang mengandung kategori kekerasan verbal. Postingan di Facebook merupakan bentuk bahasa lisan yang dituliskan di kolom komentar maupun status dengan ciri bahasa lisan tidak harus memperhatikan unsur gramatikal, hanya perlu intonasi, dan tergantung situasi, kondisi, ruang dan waktu atau ditunjang oleh 
situasi pemakaian (Subarianto, 1999). Data kekerasan verbal berupa masalah politik, sosial, ekonomi, dan agama. Sumber data diperoleh dari media sosial yang menjadi objek penelitian yaitu facebook.

Teknik pengumpulan data menggunakan dokumentasi yang diperoleh dari Facebook dengan mengakses, membaca, mencatat, dan mengelompokkan sesuai jenis kekerasan verbal. Analisis data dalam penelitian ini adalah kegiatan yang terkait dengan upaya memahami, menjelaskan, menafsirkan, dan mencari hubungan di antara data-data yang diperoleh (Ibrahim, 2015:104). Analisis data dilakukan secara kualitatif, menurut (Sugiyono, 2015:337) ada enam aktivitas dalam menganalisis data dalam penelitian ini yaitu: mendeskripsikan data, data reduction (reduksi data), mengklasifikasikan data, menginterpretasikan data, data display (penyajian data), dan conclusion drawing/verifikasi data/membuat kesimpulan.

\section{Hasil Penelitian dan Pembahasan}

\section{Hasil Penelitian}

Hasil penelitian menunjukkan bahwa bentuk bahasa yang ditemukan dalam komentar kekerasan verbal yang ditulis di media sosial dianalisis efektivitasnya dalam satuan kalimat, yaitu: 1) kelugasan; kelugasan unsur sebuah kalimat merupakan unsur yang utama dalam kalimat. Menurut (Sasangka, 2014:55) kelugasan dalam kalimat efektif mensyaratkan bahwa informasi yang akan disampaikan dalam kalimat itu ialah yang pokok-pokok saja (yang perlu-perlu atau yang penting-penting saja), tidak boleh berbelit-belit, tetapi disampaikan secara sederhana. 2) Ketepatan; ketepatan dalam kalimat efektif mensyaratkan bahwa informasi yang akan disampaikan dalam kalimat itu harus jitu atau kena benar (sesuai dengan sasaran) sehingga dibutuhkan ketelitian. Kalimat yang tepat tidak akan menimbulkan multitafsir karena kalimat yang multitafsir pasti menimbulkan ketaksaan atau keambiguan (ambiguity), yaitu maknanya lebih dari satu, menjadi kabur, atau bahkan meragukan. Kemudian, 3) kejelasan; kejelasan dalam kalimat efektif mensyaratkan bahwa kalimat itu harus jelas strukturnya dan lengkap unsurunsurnya. Kalimat yang jelas strukturnya memudahkan orang memahami makna 
yang terkandung di dalamnya, tetapi ketidakjelasan struktur bisa jadi menimbulkan kebingungan orang untuk memahami makna yang terkandung di dalamnya.

Hasil penelitian menunjukkan para pengguna media sosial khususnya Facebook (Fb) pada bulan Januari hingga Maret 2019 masih berkomentar menggunakan kata-kata, frasa, klausa yang mengandung unsur kekerasan verbal. Berdasarkan hasil penelitian yang telah dilakukan, diperoleh 36 postingan di Facebook yang mengandung komentar kekerasan verbal, dengan 118 tuturan komentar netizen di Facebook, dan terdapat 166 bentuk kekerasan verbal yang tergolong di dalam lima bentuk kategori yaitu: umpatan, hiperbola, disfemisme, stigmatisasi, dan asosiasi pada binatang. Menurut (Kesworo, 2014: 27) kekerasan verbal dibagi kedalam 6 kategori, yaitu meliputi sebagai berikut.

1. Umpatan yaitu kata-kata kasar yang mencerca, mencaci maki, menjelek jelekkan orang. Contohnya: kurang ajar, sialan.

2. Hiperbol merupakan ungkapan yang dibesar-besarkan sehingga tidak sesuai dengan sebenarnya. Contohnya: Pujian Yenny Wahit ke Jokowi kelewat matang, sampai-sampai gosong.

3. Eufimisme yaitu pengucapan gaya bahasa halus untuk menyindir atau mengkritik dengan nada yang terkesan melecehkan. Contohnya: Ada emekemak berbohong minta maaf, ada bapak-bapak berbohong kemudian minta dua periode geli gak lo!.

4. Disfemisme yaitu mengkasarkan, mengeraskan fakta melalui ucapan sehingga maknanya berbeda dari sungguhan. Contohnya: Pinjaman IMF \$35 milyar digembar-gemborkan untuk membantu Indonesia.

5. Stigmatisasi yaitu pemberian 'tanda' atau stigma terhadap seseorang atau sekelompok orang dengan pengertian yang bermakna tertentu dalam situasi dan konteks tertentu secara terbuka atau terselubung untuk mempengaruhi daya pikir atau daya evaluasi seseorang atau sekelompok orang terhadap sesuatu, demi kepentingan si pemberi stigma. Contohnya: Lebih baik punya presiden duda, dari pada punya presiden punya istri tapi diatur janda. 
6. Asosiasi pada binatang yaitu dialog yang ditunjukan kepada manusia, tetapi berasosiasi pada binatang. Contohnya: "Cari babi ini sampai dapat.", "Ada cebong nyusup di reuni 212.", dan "Rupamu seperti anjing."

\section{Pembahasan}

Bentuk bahasa dalam suatu kalimat haruslah memenuhi persyaratan gramatikal, dan juga memenuhi kaidah-kaidah yang berlaku. Menurut (Keraf, 2004:38; Noermanzah, 2017:3-4) kalimat merupakan suatu bentuk bahasa yang mencoba menyusun dan menuangkan gagasan-gagasan seseorang secara terbuka untuk dikomunikasikan kepada orang lain dengan struktur fungsi yang lengkap mulai dari subjek, predikat, objek, pelengkap, dan keterangan. Berdasarkan hasil penelitian yang telah dilakukan, bentuk bahasa yang digunakan pada media sosial Facebook dalam penyampaian pesan bergerak begitu deras, hampir tidak dapat dibendung.

Apa yang dipikirkan netizen telah menginspirasi dan memotivasi para netizen (warganet) untuk memainkan tombol-tombol keyboard gawainya, merangkai hurufhuruf menjadi kata, frasa, klausa, kalimat, paragraf, dan wacana. Ironisnya, semangat berkata-kata secara tertulis ini tidak dibarengi dengan sikap positif penggunaan bahasa. Sering sekali ditemukan ketimpangan komunikasi (miscommunication) antara penulis dan pembaca karena penggunaan bahasa, bahkan tidak jarang kita dapati kelewatan dalam berkomunikasi (lost communication) sebab pengolahan pesan yang tak terkendali atau yang sengaja dibenturkan. Hal ini tidak saja berakibat pada rusaknya sendi-sendi bahasa, tetapi juga hancurnya nilai-nilai persaudaraan antarkomunikan. Jika diperhatikan, bagaimana banyaknya komentar kekerasan verbal akhir-akhir ini. Umumnya semua itu berawal dari pesan-pesan yang diviralkan via jejaring sosial.

Pada zaman sekarang ini, penggunaan bahasa Indonesia menumbuhkan banyak varian, yang lebih dikenal dengan dialek, termasuk pula komunikasi di media sosial. Menurut Kridalaksana (2007:2) variasi bahasa berdasarkan pemakai bahasa dibedakan sebagai berikut. 
1. Dialek regional, yaitu variasi bahasa yang dipakai di daerah tertentu. Variasi regional membedakan bahasa yang dipakai di satu tempat dengan yang dipakai di tempat lain, walaupun variasi-variasinya berasal dari satu bahasa, misalnya dialek Jakarta, dialek Jawa.

2. Dialek sosial, yaitu dialek yang dipakai oleh kelompok sosial tertentu atau yang menandai stratum sosial tertentu, misalnya dialek wanita, dialek remaja.

3. Dialek temporal, yaitu dialek yang dipakai pada waktu kurun waktu tertentu, misalnya dialek melayu zaman Sriwijaya.

4. Idiolek, yaitu keseluruhan ciri-ciri bahasa seseorang. Sekalipun kita semua berbahasa Indonesia, namun kita masing-masing mempunyai ciri-ciri khas pribadi dalam lafal, tata bahasa, atau pilihan dan kekayaan kata.

Melihat bentuk bahasa kekerasan verbal pada media sosial yang dianalisis, terdapat tiga karakteristik bentuk bahasa efektifitas kalimat yang dapat ditemukan dalam media sosial yang mengandung unsur kekerasan verbal, yaitu diantaranya: kelugasan, ketepatan, dan kejelasan. Untuk kelugasan, postingan atau komentarkomentar netizen di media sosial yang mengandung kekerasan verbal sebagian besar jika dilihat dari lugas sebuah kalimat, komentar tersebut sebagian besar yang disampaikan tidak lugas. Komentar tersebut kadang kala tidak langsung pada pokok pembicaraan, tetapi terkesan berbelit-belit, sehingga menyulitkan pembaca untuk memahami maksud komentar netizen tersebut. Misalnya: komentar dari Nt79 "Emang dasar artis mata duitan otak mesum kalo jadi pejabat publik pasti korupsi kaya yh sudh".

Sementara dari segi ketepatan dalam kalimat efektif, komentar dari netizen sering kali menggunakan kata yang berambigu, sehingga terkadang netizen lain salah menafsirkan makna dari postingan yang dibaca di media sosial, sehingga netizen lain yang salah memaknai postingan berkomentar kekerasan verbal. Misalnya postingan dari P.11 "Tahukah Anda? Mendoakan orang mati maka Kita akan mendapat dosa", dari postingan dari P.11 tersebut dapat menyebabkan komentar kekerasan verbal diantaranya dari Nt11.1: "Mati dulu Baru kerasa", Nt11.2: "Iklan asu juancok", Nt11.3: "Iklan tai gigi di close gak ilang", dan Nt11.4: 
"Iklan nya bangsat!". Komentar tersebut terjadi karena netizen yang salah dalam memahami makna postingan.

Kemudian, apabila dilihat dari kejelasan struktur komentar netizen yang digunakan saat komunikasi mengandung kekerasan verbal, unsur komentar tersebut sebagian besar tidak begitu jelas sehingga pembaca terkadang sulit menentukan unsur apa saja yang ada dalam komentar tersebut. Jika dilihat dari bentuk komentar terhadap postingan di Facebook dari 166 data kekerasan verbal yang diperoleh, terdapat 98 data komentar netizen yang termasuk dalam kategori umpatan, 11 data komentar yang tergolong dalam kategori hiperbol, 37 data komentar yang tergolong dalam kategori disfemisme, 6 data komentar yang tergolong dalam kategori stigmatisasi, 14 data komentar yang tergolong dalam kategori asosiasi pada binatang. Pada dasarnya netizen mudah sekali mengomentari sebuah postingan, tanpa berpikir terlebih dahulu sebelum berkomentar. Hal tersebut dapat terjadi karena emosi sesaat atau juga sikap menirukan komentar netizen yang lain.

Dilihat dari segi bentuk komentar terhadap postingan di Facebook, pada dasarnya tidak semua postingan di media sosial menampilkan unsur kekerasan verbal, tetapi hanya berupa berita biasa yang memberikan informasi kepada netizen tentang berita teraktual yang sedang diberitakan saat itu. Berita-berita terbaru dan marak diberitakan serta dikomentari dengan kekerasan verballah yang hanya diambil oleh peneliti. Hal tersebut terkadang data tentang artis yang banyak memiliki netizen tidak diambil oleh peneliti, karena pada saat peneliti telah selesai melakukan penelitian, barulah artis tersebut muncul dalam pemberitaan di media sosial.

Bentuk komentar kekerasan verbal ini dapat dikatakan sebuah kekerasan dalam komunikasi tergantung dengan konteks pembicaraannya. Konteks pembicaraan sangat menentukan sebuah kata-kata, klausa, atau kalimat tersebut merupakan sebuah kekerasan verbal. Misalnya "Tangkap anjing itu." kalau kata anjing itu benar merupakan binatang maka bukan merupakan kekerasan verbal, tetapi kalau anjing tersebut merupakan orang (asosiasi pada binatang) maka tergolong ungkapan kekerasan verbal. Netizen berkomentar menggunakan 
kekerasan verbal karena terpengaruh dengan postingan ataupun komentar netizen lain yang dibaca, sehingga ikut-ikutan dalam melakukan komentar.

Media sosial belum mempunyai fitur atau aplikasi yang dapat menyensor konten atau komentar yang mengandung kekerasan verbal yang diposting sehingga semua komentar apapun yang kita posting akan langsung terposting secara otomatis tanpa ada persetujuan dari media sosial. Hal tersebut dapat menjadi hal yang buruk secara psikologis apabila dibaca oleh anak usia sekolah (Hana \& Suwarti, 2020).

Pada dasarnya netizen yang berkomentar menggunakan kekerasan verbal adalah orang-orang yang tidak berpendidikan ataupun orang yang berpendidikan, tetapi memiliki karakter yang buruk. Mereka merupakan orang-orang yang mudah terpancing, dengan sesuatu yang mereka baca tanpa mengecek kebenarannya.

Dalam penelitian ini, peneliti mengkaji beberapa penelitian terdahulu sebagai bahan pertimbangan ataupun sebagai referensi yang memiliki kesamaan maupun perbedaan. Terdapat beberapa penelitian sejenis yang membahas kekerasan verbal seperti: penelitian (Nisa \& Wahid, 2014) dengan judul Analisis Isi Kekerasan Verbal dalam Sinetron "Tukang Bubur Naik Haji The Series" di RCTI (Analisis Isi Episode 396-407) yang dipublikasikan di Jurnal Komunikasi Fakultas IImu Komunikasi Universitas Budi Luhur, membahas presentase kecenderungan muatan kekerasan verbal dalam tayangan sinetron Tukang Bubur Naik Haji The Series, persamaannya dengan penelitian ini sama-sama meneliti sebuah konten yang mengandung unsur kekerasan verbal, objek penelitian yang digunakan dalam penelitian Nisa \& Wahid (2014) adalah sinetron yang ditayangkan di televisi.

Peneliti memanfaatkan penelitian dari Nisa \& Wahid (2014) untuk melihat kategori dan indikator dari kekerasan verbal yang ditemukan sebagai referensi bentuk komentar kekerasan verbal. Kategori tersebut misalnya: kata-kata kasar, mengancam, dan menghina. Selanjutnya untuk indikatornya misalnya: kata-kata kasar; sialan, goblok, kampret; mengancam misalnya: hajar, musnahkan, usir, menghina misalnya: iblis, nenek lampir, dan orang gila. 
Sementara itu, penelitian yang dilakukan oleh Putra (2015) yang dipublikasi di Ejournal IImu Komunikasi Fisip Universitas Mulawarman dengan judul Analisis Isi Kekerasan Verbal pada Tayangan Pesbukers dI ANTV. Menganalisis persentase kecenderungan muatan kekerasan verbal dalam tayangan Pesbukers yang berbentuk komedi, persamaannya dengan penelitian ini sama-sama meneliti sebuah konten yang mengandung unsur kekerasan verbal, sementara itu perbedaannya adalah objek penelitian yang digunakan dalam penelitian ini adalah hiburan komedi yang ditayangkan di televisi.

Peneliti memanfaatkan penelitian Putra (2015) untuk dijadikan referensi dalam pengkategorian bentuk kekerasan verbal, kategori kekerasan verbal yang dikelompokkan oleh Putra (2015) terdiri dari 5 kategorisasi, yaitu: asosiasi pada binatang, umpatan, hiperbol, eufemisme, dan disfemisme.

Melihat dari persamaan dan perbedaan antara penelitian yang telah dilakukan (Nisa \& Wahid, 2014) dan (Putra, 2015) dengan penelitian yang dilakukan peneliti ini, dapat disimpulkan bahwa penelitian yang telah dilakukan oleh peneliti sangat berbeda dengan peneliti sebelumnya karena penelitian ini objek penelitiannya adalah media sosial Facebook dan bahasannya bentuk bahasa dan komentar dalam media sosial sehingga dapat dikatakan penelitian tentang analisis kekerasan verbal dalam media sosial bukanlah sebuah replikasi.

Dengan demikian, bentuk bahasa yang digunakan dalam kalimat Facebook memiliki kelugasan, ketepatan, dan kejelasan. Sementara itu, bentuk komentar terhadap postingan di Facebook berupa kekerasan verbal meliputi: umpatan, hiperbola, disfemisme, stigmatisasi, dan asosiasi pada binatang. Bahasa kekerasan verbal yang ada di Facebook menunjukkan bahwa masyarakat Indonesia masih belum santun dalam berbahasa sehingga menjadi masukan bagi pemerintah, lembaga pendidikan, lembaga sosial, lembaga agama, lembaga lainnya untuk memberikan langkah strategis untuk mengatasi permasalahan tersebut. Apabila kekerasan verbal ini tidak ditindaklanjuti oleh seluruh elemen bangsa maka bangsa ini bisa menjadi bangsa yang bisa diadu domba dan akan memudarkan rasa persatuan dan kesatuan bangsa. 


\section{Simpulan}

Berdasarkan hasil penelitian dan pembahasan yang telah dipaparkan di atas, dapat disimpulkan bahwa: (1) bentuk bahasa yang digunakan dalam media sosial Facebook, dilihat dari efektifitas kalimatnya memiliki karakteristik: kelugasan, ketepatan, dan kejelasan, (2) bentuk komentar terhadap postingan di Facebook berupa: umpatan, hiperbol, disfemisme, stigmatisasi, dan asosiasi pada binatang. Sebuah komentar kekerasan verbal ini dapat dikatakan sebuah kekerasan dalam komunikasi tergantung dengan konteks pembicaraannya. Konteks pembicaraan sangat menentukan sebuah kata-kata, klausa, atau kalimat tersebut merupakan sebuah kekerasan verbal. Selain hal tersebut, makna yang terkandung sebuah komentar juga menentukan apakah komentar tersebut mengandung unsur kekerasan verbal atau tidak.

Harapannya bagi warganet yang berkaitan dengan komunikasi yang kita lakukan khususnya di media sosial Facebook hendaklah kita selalu beretika dalam melakukan komunikasi, baik itu secara langsung maupun tidak langsung. Jangan sampai menggunakan komunikasi yang mengandung unsur kekerasan verbal. Karena hal tersebut dapat merugikan diri sendiri maupun orang lain. Saat ini transaksi elektronik pula telah ada dasar hukumnya, apabila kita salah dalam berkomunikasi, bisa saja kita dijerat dengan UU ITE RI.

\section{Daftar Pustaka}

Asmaya, F. \& Rumyeni. (2015). Pengaruh Penggunaan Media Sosial Facebook terhadap Perilaku Prososial Remaja di Kenagarian Koto Bangun. Jurnal Online Mahasiswa (JOM) Bidang IImu Sosial dan IImu Politik, 2(2), https://jom.unri.ac.id/index.php/JOMFSIP/article/view/7543

Bungin, B. (2008). Metotologi Penelitian Kualitatif Aktualisasi Metodologis ke Arah Ragam Varian Kontemporer. Jakarta: Raja Grafindo Persada.

Effendy, O. U. (2003). IImu, Teori, dan Filsafat Komunikasi. Bandung: Citra Aditya Bakti.

Fitriana, Y., Pratiwi, K., \& Sutanto, A. V. (2015). Faktor-Faktor yang Berhubungan dengan Perilaku Orang Tua dalam Melakukan Kekerasan Verbal terhadap 
Anak Usia Pra-Sekolah. Jurnal Psikologi Undip, 14(1). doi:10.14710/jpu.14.1.81-93

Hana, D. R., \& Suwarti, S. (2020). Dampak Psikologis Peserta Didik yang Menjadi Korban Cyber Bullying. Psisula: Prosiding Berkala Psikologi, 1. doi:10.30659/psisula.v1i0.7685

Handayani, J. S. (2009). Nggak Kuper \& Ngebisnis Lewat Facebook. Jakarta: Niaga Swadaya.

Hidaya, N., \& Khusnia, D. (2019). Analisa Sosial Media Facebook terhadap Pola Interaksi Sosial dan Perilaku Remaja di SMA Negeri 3 Kota Sorong. Jurnal Noken: Ilmu-IImu Sosial, 4(2), 129. doi:10.33506/jn.v4i2.496

Ibrahim. (2015). Metodologi Penelitian Kualitatif. Bandung: Alfabeta.

Keraf, G. (2004). Komposisi. Flores: Nusa Indah.

Kesworo, R. W. (2014). "Kekerasan Verbal dan Non Verbal pada Tayangan Komedi di Televisi (Analisis Isi pada Tayangan Komedi Pesbukers Episode 23 Mei 2013 dan 23 Juli 2013)". Malang: University of Muhammadiyah Malang.

Kridalaksana, H. (2007). Pembentukan Kata dalam Bahasa Indonesia. Jakarta: Gramedia Pustaka Utama.

Lestari, T. (2016). Verbal Abuse Dampak Buruk dan Solusi Penanganannya pada Anak. Yogyakarta: Psikosain.

Nisa, A. C., \& Wahid, U. (2014). Analisis Isi Kekerasan Verbal dalam Sinetron "Tukang Bubur Naik Haji The Series" di RCTI (Analisis Isi Episode 396407). Jurnal Komunikasi, 9(1), 85-102. doi:10.20885/komunikasi.vol9.iss1.art7

Noermanzah, N. (2017). Struktur Kalimat Tunggal Bahasa Sindang di Kota Lubuklinggau dan Pengaruhnya dalam Pembelajaran Bahasa Indonesia. AKSIS: Jurnal Pendidikan Bahasa dan Sastra Indonesia, 1(1), 3-4. doi:10.21009/aksis.010101

Noermanzah, N. (2019). Bahasa sebagai Alat Komunikasi, Citra Pikiran, dan Kepribadian. Seminar Nasional Pendidikan Bahasa dan Sastra, Prosiding Seminar Nasional Bulan Bahasa (Semiba), 307, https://ejournal.unib.ac.id/index.php/semiba/article/view/11151/5537 
Nugroho, A. (2018). Nilai Sosial dan Moralitas dalam Naskah Drama Janji Senja Karya Taofan Nalisaputra. Silampari Bisa: Jurnal Penelitian Pendidikan Bahasa Indonesia, Daerah, dan Asing, 1(2), 28-42. doi:10.31540/silamparibisa.v1i2.153

Putra, S. A. (2015). Analisis Isi Kekerasan Verbal pada Tayangan Pesbukers dl ANTV. E-Journal IImu Komunikasi, 3(1), https://ejournal.ilkom.fisipunmul.ac.id/site/?p=1828

Sasangka, S. S. T. W. (2014). Seri Penyuluhan Bahasa Indonesia Kalimat. Jakarta: Kemendikbud.

Simbolon, M. (2012). Perilaku Bullying pada Mahasiswa Berasrama. Jurnal Psikologi, 39(2), https://jurnal.ugm.ac.id/jpsi/article/view/6989

Subarianto, J. (1999). Kebakuan dan Ketidakbakuan Kalimat dalam Bahasa Indonesia. Yogyakarta: Mitra Gama Widya.

Sugiyono. (2015). Metode Penelitian Pendidikan Pendekatan Kuantitatif, Kualitatif, dan R\& D. Bandung: Alfabeta.

Wardani, L. K., \& Fajriansyah, F. (2017). Perilaku Bullying Mahasiswa Kesehatan. Journal of Nursing Practice, 1(1), 18. doi:10.30994/jnp.v1i1.18 